\title{
ANALISIS MANAJEMEN BAHAN BAKAR PADA KONSEPTUAL DESAIN TERAS KONVERSI TRIGA 2000
}

\author{
Lily Suparlina dan Tukiran Surbakti \\ Pusat Teknologi dan Keselamatan Reaktor Nuklir-BATAN \\ Kawasan Puspiptek Gd 80 Tangerang Selatan, Banten.
}

\begin{abstract}
ABSTRAK
ANALISIS MANAJEMEN BAHAN BAKAR PADA KONSEPTUAL DESAIN TERAS KONVERSI TRIGA 2000. Manfaat yang luas penggunaan reaktor riset membuat banyak negara membangun reaktor riset baru. Kecenderungan saat ini adalah tipe reaktor serbaguna dengan teras kompak untuk mendapatkan fluks neutron yang tinggi dengan daya yang relatif rendah. Reaktor riset di Indonesia relatif sudah tua. Oleh karena itu diperlukan desain reaktor riset baru sebagai alternatif atau modifikasi desain, kelak pengganti reaktor riset yang sudah ada. Tujuan dari riset ini untuk melengkapi data desain teras TRIGA Bandung sebagai salah satu parameter penting dan dibutuhkan untuk menyusun LAK serta persyaratan untuk perizinan desain. Perhitungan dilakukan untuk memahami pola operasi dan manajemen bahan bakar reaktor TRIGA Bandung dengan konfigurasi teras setimbang yang optimal terdiri dari 16 bahan bakar dan 4 batang kendali dengan grid teras $5 \times 5$ dan daya 2 MW. Perhitungan manajemen bahan bakar desain teras TRIGA Bandung dilakukan untuk bahan bakar U3Si2-Al dengan kerapatan 2,96 gU/cc. Perhitungan dilakukan dengan paket program WIMSD-5B dan BATAN-FUEL. Hasil pehitungan menunjukkan bahwa dengan pola operasi satu dan dua, parameter operasi tidak ada yang dilampaui. Namun hal ini tidak dapat digunakan untuk menambah peningkatan fraksi bakar. Dalam hal ini tidak ditemukan peningkatan fraksi bakar yang signifikan dengan hanya merubah konfigurasi teras, hanya bisa memperpanjang siklus operasi.
\end{abstract}

Kata kunci: desain konseptual, bahan bakar uranium-silisida, manajemen bahan bakar, WIMSD-5B, BATAN-FUEL

\begin{abstract}
ANALYSIS OF FUEL MANAGEMENT FOR CONCEPTUAL DESIGN OF THE TRIGA2000 CONVERSION CORE. The board benefits of using research reactors have led many countries to build new research reactors. The current trend is a multipurpose reactor type with a compact core to obtain a high neutron flux at a relatively low power. Research reactors in Indonesia are relatively old. Therefore, it is necessary to design a new research reactor as an alternative or design modification, one day to replace the existing research reactor. The purpose of this research is to complement the TRIGA Bandung core design data as one of the important parameters needed to compile the SAR and the requirements for design licensing. The calculations were carried out to understand the operating pattern and in-core fuel management level of the TRIGA Bandung reactor with an optimal equilibrium core configuration consisting of 16 fuels and 4 control rods with a $5 \times 5$ core grid and $2 \mathrm{MW}$ power. The fuel management calculation for the TRIGA Bandung core design was carried out for U3Si2-Al fuel with a density of 2.96 $\mathrm{gU} / \mathrm{cc}$. The calculations were carried out with the WIMSD-5B and BATAN-FUEL program codes. The calculation results show that with one and two operating patterns, none of the operating parameters are exceeded. However, this cannot be used to increase the burn-up fraction. In this case there is no significant increase in the burn-up fraction by changing the core configuration, only extending the operating cycle.
\end{abstract}

Keywords: conceptual design, urium-silicide fuel, fuel management, WIMS5D-5B, BATAN-FUEL 


\section{PENDAHULUAN}

Penggunaan reaktor riset

TRIGA2000 Bandung konversi adalah untuk keperluan produksi radioisotop, aktivasi neutron, penelitian, uji material, dan pelatihan. Oleh karena itu reaktor riset ini memberikan kontribusi besar terhadap perkembangan industri, energi, kesehatan dan lingkungan, terutama aplikasi radioisotop dalam bidang kesehatan dan industri [1].

Teras konversi TRIGA2000 adalah teras triga yang mengunakan bahan bakar silinder dikonversi menjadi teras berbahan bakar tipe pelat. Reaktor TRIGA Mark II, yang awalnya beroperasi hanya pada daya $250 \mathrm{~kW}$ [2] kemudian di upgrade menjadi $2000 \mathrm{~kW}$. Modifikasi ini dapat dituntaskan pada awal tahun 2000 [3].

\section{Reaktor TRIGA 2000 Bandung} masih beroperasi dengan menggunakan elemen bakar TRIGA standar. Pengoperasian reaktor elemen bakar TRIGA standar sangat bergantung pada pasokan bahan bakar dari General Atomic (GA), saat ini GA sebagai pemasok bahan bakar standar reaktor TRIGA tidak memproduksi lagi bahan bakar reaktor TRIGA tersebut. Sementara itu, INUKI Serpong telah dapat memproduksi bahan bakar tipe pelat yang telah digunakan untuk reaktor RSG-GAS. Kenyataan ini membuktikan adanya penguasaan teknologi bahan bakar oleh Indonesia, sehingga dapat dijadikan modal bagi BATAN terutama PSTNT sebagai pengelola reaktor TRIGA 2000 Bandung untuk melakukan lompatan teknologi guna menjaga keberlangsungan beroperasinya reaktor TRIGA2000 Bandung untuk waktu yang lama. Oleh karena itu, gagasan untuk melakukan konversi reaktor TRIGA 2000 Bandung dengan mengganti bahan bakar berbentuk batang menjadi bentuk pelat, dengan memanfaatkan bahan bakar buatan INUKI, produksi dalam negeri sendiri merupakan gagasan yang sangat baik, sehingga reaktor TRIGA Bandung tidak tergantung pasokan bahan bakar dari negara lain. Secara spesifik utilisasi reaktor hasil konversi ini akan digunakan untuk memproduksi radioisotope $\mathrm{I}-131, \mathrm{Br}-82$, $\mathrm{P}-$ 32 dan Mo-99 pada fasilitas CIP dan IP. Selain itu Reaktor riset TRIGA konversi Tipe Pelat Bandung ini juga menyediakan fasilitas iradiasi untuk penelitian AAN (Analisis Aktivasi Neutron) spektrometri neutron dan radiografi neutron.

Rancangan neutronik yang meliputi manajemen bahan bakar di dalam teras dan termohidrolik yang meliputi analisis distribusi temperatur, distribusi fluks neutron, perpindahan panas konveksi, distribusi laju alir, distribusi tekanan kanal terpanas, desain reflektor berbahan bakar pelat, dan rancangan sistem pendingin primer yang dilengkapi dengan sistem tangki tunda telah selesai. 
Desain teras Reaktor Riset Tipe Pelat Bandung dimulai dari pencarian konfigurasi teras yang paling optimal dengan mempertimbangkan parameter neutronik untuk keselamatan operasi reaktor. Tujuan utama dalam desain teras adalah mendapatkan teras dengan fluks neutron termal dan cepat yang tinggi dan siklus operasi yang panjang dan faktor keselamatan operasi yang tinggi. Dengan manajemen teras dan penanganan reaktivitas yang optimal akan diperoleh desain teras reaktor riset tipe pelat Bandung yang paling optimal. Dalam penelitian ini dilakukan hanya perhitungan manajemen teras dengan pola pemuatan bahan bakar yang berbeda.

Perhitungan desain teras menggunakan program WIMSD/5B untuk menggenerasi tampang lintang bahan bakar dan bahan lain dalam teras reaktor. Untuk menentukan konfigurasi teras dilakukan dengan menggunakan metode deterministik menggunakan program BATAN-FUEL.

\section{DESKRIPSI DESAIN TERAS TRIGA}

Perangkat elemen bakar didasarkan pada teknologi Material Testing Reactor (MTR). Setiap elemen bakar standar terdiri atas bagian ujung di bawah, dan perangkat pemegang di bagian atas, dua pelat samping dan 21 pelat elemen bakar. Setiap pelat elemen bakar terdiri atas rangka $\mathrm{AlMg} 2$ dan dua lembaran penutup dari bahan yang sama, yang membungkus pelat meat dispersi $\mathrm{U}_{3} \mathrm{Si}_{2} \mathrm{Al}$.

Elemen bakar kendali dirancang berbentuk kotak sehingga memberikan keefektifan tinggi untuk kendali dan pemadaman reaktor. Elemen bakar kendali dirancang untuk dapat disisipi penyerap jenis garpu (fork type). Bagian yang berisi elemen bakar pada elemen bakar kendali identik dengan bagian yang berisi elemen bakar pada elemen bakar. Sebanyak 15 pelat elemen bakar bagian dalam ditahan oleh dua pelat samping. Sebanyak 3 (tiga) pelat elemen bakar diambil pada setiap ujung dari daerah yang berisi elemen bakar untuk memberikan ruang untuk memasukkan bilah penyerap (absorber blade). Pelat-pelat Aluminium menggantikan dua dari tiga pelat elemen bakar yang diambil. Perangkat penyerap terdiri atas dua bilah Ag-In-Cd yang diberi lapisan baja tahan karat (bahan 1,4541, sama dengan SS 321). Tabel 1 menyatakan data geometri perangkat bahan bakar reaktor TRIGA Bandung konversi. Konfigurasi teras konversi TRIGA 2000 dapat dilihat pada Gambar 1. 


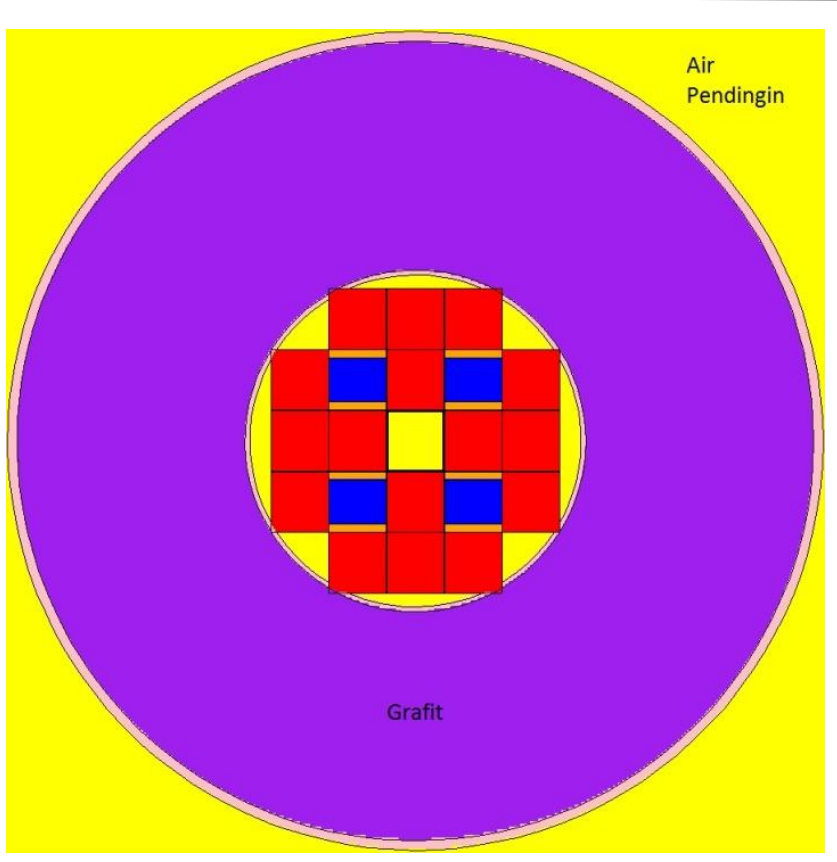

Keterangan:

warna merah = elemen bakar standar

warna biru= elemen bakar kendali

warna jingga $=$ bilah absorber

warna kuning $=$ air ringan

Gambar 1. Konfigurasi teras TRIGA konversi

Tabel 1. Desain perangkat bahan bakar teras TRIGA konversi [12]

\begin{tabular}{lc}
\hline Parameter & Nilai \\
\hline Jumlah elemen bakar standar di dalam teras & 16 \\
Pelat elemen bakar per elemen bakar standar & 21 \\
Jumlah elemen bakar kendali pada teras & 4 \\
Pelat elemen bakar per elemen bakar kendali & 15 \\
Dimensi elemen bakar standar dan elemen kendali, mm & $77,1 \times 81 \times 600$ \\
Ketebalan pelat bahan bakar, mm & 1,3 \\
Lebar kanal pendingin, mm & 2,55 \\
Jumlah pelat bahan bakar di elemen bakar & 21 \\
Jumlah pelat bahan bakar di elemen kendali & 15 \\
Material kelongsong & $\mathrm{AlMg} 2$ \\
Material pelat sisi & $\mathrm{AlMg} 2$ \\
Ketebalan kelongsong bahan bakar, mm & 0,38 \\
Dimensi zona aktif, mm & $0,54 \times 62,75 \times 600$ \\
Material bahan bakar & $\mathrm{U}_{3} \mathrm{Si} \mathrm{i}_{2}-\mathrm{Al}$ \\
Pengkayaan, $\%$ & 19,75 \\
Muatan massa ${ }^{235} \mathrm{U}, \mathrm{g}$ & 250 \\
Material penyerap & $\mathrm{AgInCd}$ \\
Ketebalan penyerap, mm & 3,38 \\
Material kelongsong penyerap & $\mathrm{SS}-321$ \\
Ketebalan kelongsong penyerap & 0,85 \\
Tebal meat, cm & 0,054 \\
Tebal kelongsong, cm & 0,038 \\
Lebar kanal pendingin, cm & 0,255 \\
Dimensi kisi teras, cm $\times$ cm & $8,1 \times 7,71$ \\
\hline
\end{tabular}




\section{Program Komputer WIMSD-5B}

Winfrith Improved Multigroup Scheme (WIMS) [13, 16, 17] banyak digunakan untuk perhitungan reaktor dengan berbagai jenis reaktor termal. WIMS terdiri dari program komputer lattice transport dan daftar pustaka (library) yang bersesuaian [16]. Secara khusus, program WIMS ini akan menerima geometri bahan bakar batang atau pelat baik dalam susunan biasa atau dalam kelompok dan struktur kelompok energi yang telah dipilih terutama untuk perhitungan reaktor termal. Pustaka dasar telah dikompilasi dengan 14 grup neutron cepat, 13 grup neutron resonansi, dan 42 grup neutron termal, tetapi user ditawarkan pilihan solusi akurat dalam banyak grup atau perhitungan cepat dalam beberapa grup. Matriks hamburan termal yang bergantung pada suhu untuk berbagai hukum hamburan dimasukkan dalam perpustakaan untuk moderator utama yang meliputi hidrogen, deuterium, grafit, berilium, dan oksigen. Karena dimensi variabel digunakan dalam WIMS, tidak ada batasan khusus pada parameter seperti jumlah kelompok energi atau interval mesh selain batasan keseluruhan pada penyimpanan teras komputer yang digunakan. Pustaka tampang lintang ( $x$-section) hanya memiliki 69 kelompok energi. Fleksibilitas diberikan untuk menjalankan masalah dengan jumlah kelompok yang lebih sedikit.

\section{METODOLOGI}

Diameter teras reaktor TRIGA berbahan bakar TRIGA standar adalah 533,4 mm seperti yang ditunjukkan pada Gambar 2. Oleh karena itu, jika bahan bakar TRIGA standard diganti dengan bahan bakar dan elemen kendali dengan dimensi $77,1 \mathrm{~mm} \mathrm{x}$ $81 \mathrm{~mm}$, maka diameter teras perlu dibagi menjadi $533,4 \mathrm{~mm} / 81 \mathrm{~mm}=6$ satuan. Penampang teras berbentuk lingkaran maka jumlah bahan bakar yang mungkin dimasukkan ke teras menjadi 21 buah, seperti ditunjukkan pada Gambar 2.

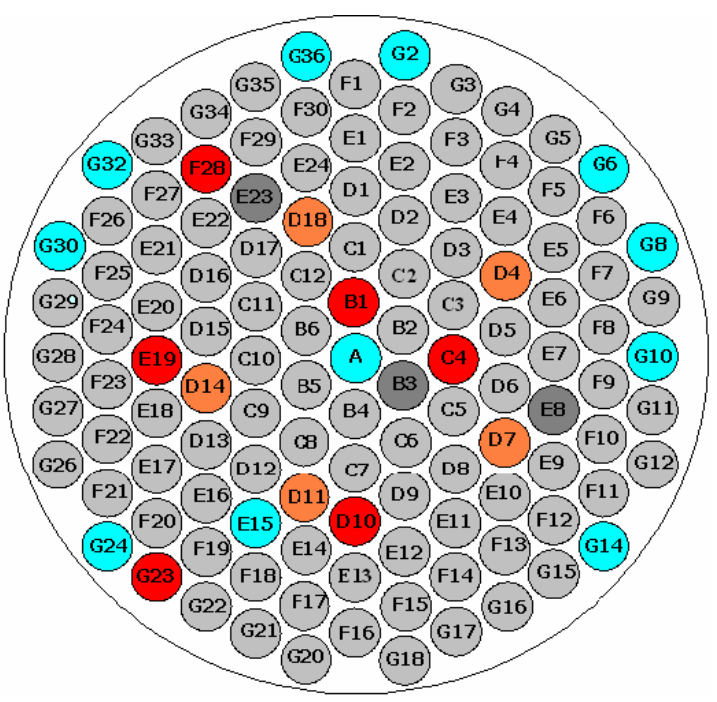

Gambar 2. Konfigurasi teras TRIGA [14]

\section{Keterangan:}

$\mathrm{A}=$ berisi air

$\mathrm{B}=$ bahan bakar dengan fraksi kelas pertama

$\mathrm{C}=$ bahan bakar dengan fraksi bakar kelas ke 2

$\mathrm{D}=$ batang kendali

$\mathrm{E}=$ bahan bakar dengan fraksi bakar kelas ke 3 $\mathrm{F}=$ bahan bakar dengan fraksi bakar kelas ke 4 $\mathrm{G}=$ bahan bakr dengan fraksi bakar kelas ke 5

Tampang lintang makroskopis bahan bakar dan batang kendali dan material pembentuk teras reaktor merupakan input program 
BATAN-FUEL pada perhitungan desain teras TRIGA2000 berbahan bakar pelat. Perhitungan tampang lintang bahan bakar dan bahan non fisil dilakukan dengan program WIMSD/5. Perhitungan sel bahan bakar, batang kendali dan material pembentuk teras dilakukan dalam empat kelompok energi dimana daerah neutrón cepat $0,821 \mathrm{MeV}<\mathrm{E} \leq 10 \mathrm{MeV}$, daerah slowing down $5,53 \mathrm{keV}<\mathrm{E} \leq 0,821$, daerah resonansi $0,625<\mathrm{E} \leq 5,53 \mathrm{keV}$ dan daerah termal 0,625 $<\mathrm{E} \leq 0,0 \mathrm{eV}$ [15]. Sementara itu kondisi operasi pada dingin dan panas bebas $\mathrm{Xe}$ dan $\mathrm{Sm}$ dan dingin dan panas bebas Xe dan Sm setimbang. Program akan menggenerasi konstanta kelompok yang disebut koefesien difusi D, tampang lintang serapan $\Sigma$ a dan tampang lintang produksi $v \Sigma$ f. Dengan cara yang sama akan dilakukan perhitungan sel batang kendali, reflektor grafit dan daerah non bahan bakar. Ini merupakan instruksi untuk persiapan data input standar untuk perhitungan pembakaran kisi dan analisis deplesi bahan bakar. Seperti yang dipersyaratkan, isotop plutonium $\left({ }^{239} \mathrm{Pu}\right)$ dimasukkan sebagai jejak dalam komposisi isotop dari bahan yang dapat dibakar (bahan bakar). 69 grup energi neutron digunakan dalam melakukan kalkulasi transport multigroup. Secara khusus, ordinat diskrit model spasial yang memecahkan bentuk diferensial dari persamaan transport neutron. Pendekatan dengan metode $\mathrm{SN}(\mathrm{N}=4)$ diadopsi untuk solusi transport neutron multigroup. $\mathrm{T}$ waktu tinggal bahan bakar dan daya spesifik Ps, disebut peringkat daya adalah data parameter yang diperlukan untuk spesifikasi pada kartu POWERC.

Paket program perhitungan sel (cell atau lattice) digunakan untuk menghitung distribus fluks neutron dan faktor perlipatan neutron tak hingga dari sel bahan bakar. Diperlukan masukan tampang lintang neutron beberapa nuklida, deskripsi geometri sel dan menyelesaikan persamaan transport neutron untuk seluruh daerah sel. Sel yang digunakan berupa unit sel dan paket perhitungan sel memasukkan persamaan transport neutron untuk mendapatkan distribusi fluks neutron dan faktor perlipatan tak hingga (k-inf) dalam kelompok tenaga neutron dan fungsi ruang. Dalam studi saat ini, unit sel yang ditangani oleh WIMSD secara mendasar terdiri dari 4 daerah yaitu bahan bakar (1), dan atau kelongsong (2), pendingin (3) dan moderator (4) yang direpresentasikan dalam geometri pelat sering disebut dengan slab. Gambar 3 mengilustrasikan elemen bahan bakar standar teras TRIGA konversi. Dimana $\mathrm{H}_{2} \mathrm{O}$ dihomogenisasi dengan uranium silisida dan kelongsong. Setiap kasus dipilih untuk mewakili set individu. Spesifikasi umum dari parameter perangkat bahan bakar reaktor TRIGA dirangkum dalam Tabel 1. Representasi geometris dari kisi bahan bakar elemen kendali dimodelkan pada Gambar 4. Reaksi isotop ${ }^{235} \mathrm{U}$ dan ${ }^{238} \mathrm{U}$ pada temperatur 
$20^{\circ} \mathrm{C}$ dihitung dalam kisi perangkat menggunakan program WIMSD-5B.

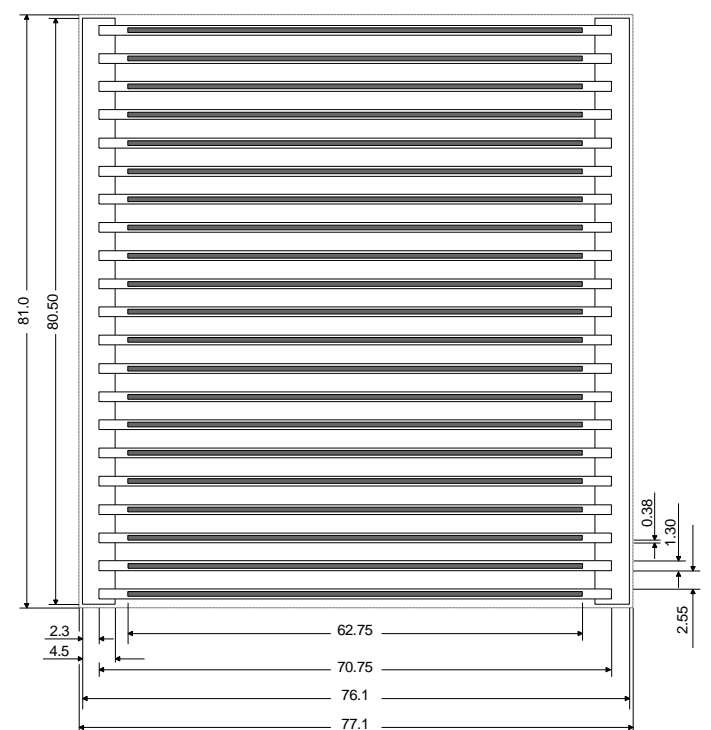

Gambar 3. Elemen bakar standard [16].

Keterangan : ukuran dalam satuan (mm)

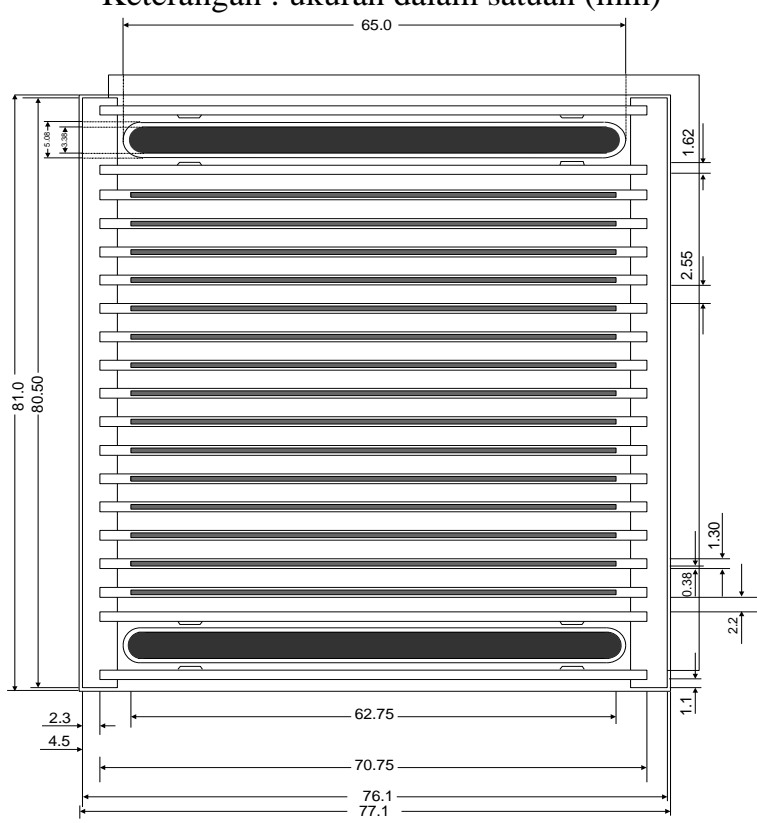

Gambar 4. Elemen bakar kendali dengan absorber AgInCd [17].

Keterangan : ukuran dalam satuan (mm)

Parameter integral yang dihitung adalah faktor multiplikasi tak terhingga (k-inf), tampang lintang makroskopik seperti koefisien difusi, tampang lintang absorbsi, tampang lintang removal, nu-fisi untuk kelompok energi 69 yang dihitung dengan energi termal $0,625 \mathrm{eV}$.
Komposisi dan radius yang mewakili sel didefenisikan dalam data material dan spektrum yang disesuaikan dengan keempat daerah tersebut dan hal ini sudah dilakukan oleh paket program WIMSD-5B. Jika tidak ingin materialnya dibobot oleh spektrum yang ada, maka diberi tanda negatif agar terjadi pengabaian. Hal ini terutama perlu dilakukan jika menghadapi sel berpenyerap kuat. Dengan menggunakan bentuk spektrum tersebut dilakukan perhitungan sel. Konsep ini mengindikasikan paket program WIMSD5B memakai penyederhanaan untuk mendapatkan hasil yang akurat.

Secara umum, identifikasi komposisi material bahan bakar yang terdiri dari kelongsong, bahan bakar dan air. Bahan bakar $\mathrm{U}_{3} \mathrm{Si}_{2} \mathrm{Al}$ dan kelongsong adalah AlMg2. Kerapatan atom untuk bahan bakar dicantumkan pada Tabel 2 dan kelongsong serta pendingin dalam Tabel 3. Kerapatan atom dan ID WIMSD-5B diimplementasikan dalam kode sebagai argumen ke kartu MATERIAL. Temperatur untuk bahan bakar $69,52^{\circ} \mathrm{C}$ dan kelongsong diatur ke $68,52^{\circ} \mathrm{C}$ serta pendingin $48,12^{\circ} \mathrm{C}$. Perhitungan densitas atom dihitung dengan menggunakan rumus $\quad \mathrm{N}_{\mathrm{i}}=0,6022 \rho_{\mathrm{i}} / \mathrm{A}_{\mathrm{i}}$ atom $/ \mathrm{cm}^{3}$ barn [17]. 
Tabel 2. Densitas atom untuk bahan bakar TRIGA

\begin{tabular}{llll}
\hline Material & WIMS & $\%$ berat & $\mathrm{T}\left({ }^{\circ} \mathrm{C}\right)$ \\
& ID & & \\
\hline $\mathrm{U}-235$ & 2235.0 & $1,50025 \mathrm{E}-03$ & 69,15 \\
$\mathrm{U}-238$ & 8238.0 & $6,01895 \mathrm{E}-03$ & \\
$\mathrm{U}-239$ & 6239.0 & $1,00000 \mathrm{E}-27$ & \\
$\mathrm{Al}$ & 27 & $5,01267 \mathrm{E}-03$ & \\
$\mathrm{Si}$ & 29 & $4,30311 \mathrm{E}-02$ & \\
\hline
\end{tabular}

Penentuan temperatur bahan bakar, kelongsong dan air digunakan seperti temperatur reaktor RSG-GAS beroperasi normal, sehingga ketiga material tersebut dibedakan temperaturnya. Kelongsong bahan bakar TRIGA2000 adalah AlMg2.
Tabel 3. Densitas atom untuk kelongsong dan moderator

\begin{tabular}{cccc}
\hline Material & WIMS & densitas & $\mathrm{T}\left({ }^{\circ} \mathrm{C}\right)$ \\
& ID & & \\
\hline $\mathrm{Mg}$ & 24 & $1,36127 \mathrm{E}-03$ & 68,52 \\
$\mathrm{Si}$ & 29 & $1,72395 \mathrm{E}-04$ & \\
$\mathrm{Cu}$ & 3063 & $1,26989 \mathrm{E}-05$ & \\
$\mathrm{Mn}$ & 55 & $8,81320 \mathrm{E}-05$ & \\
$\mathrm{Fe}$ & 2056 & $1,15597 \mathrm{E}-04$ & \\
$\mathrm{Cr}$ & 52 & $9,31187 \mathrm{E}-05$ & \\
$\mathrm{Ti}$ & 48 & $3,37079 \mathrm{E}-05$ & \\
$\mathrm{Al}$ & 27 & $5,76030 \mathrm{E}-02$ & \\
$\mathrm{H}$ & 3001 & $6,60806 \mathrm{E}-02$ & 48,12 \\
$\mathrm{O}$ & 6016 & $3,30403 \mathrm{E}-02$ & \\
\hline
\end{tabular}

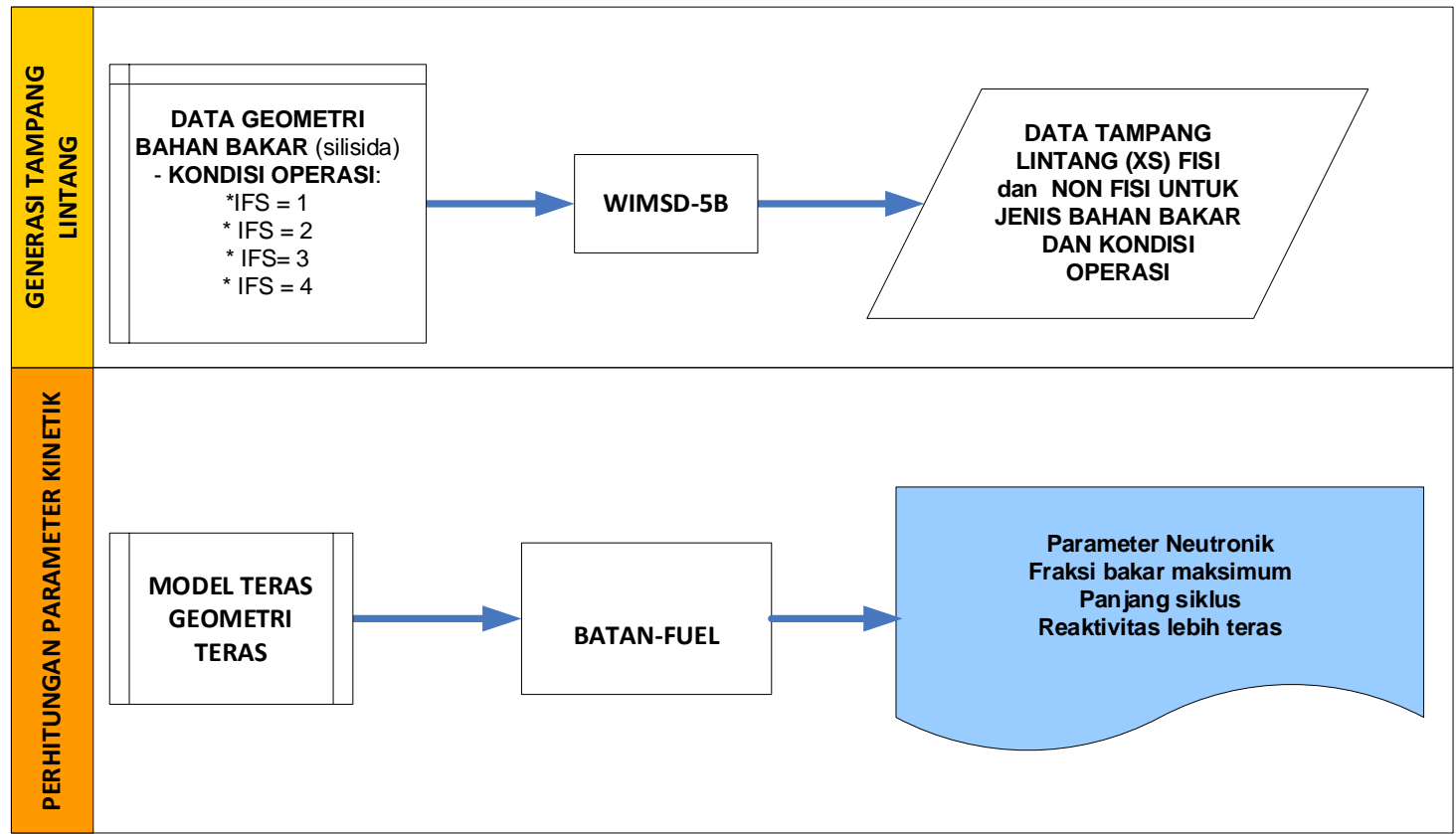

Gambar 5. Diagram alir perhitungan parameter neutronik teras TRIGA konversi [16]

\section{HASIL DAN PEMBAHASAN}

\section{Perhitungan Sel}

Berdasarkan bentuk konfigurasi teras setimbang yang terpilih dinyatakan dalam Gambar 1 yaitu konfigurasi teras $5 \times 5$. Hasil perhitungan teras setimbang reaktor TRIGA untuk konfigurasi teras dapat dilihat pada Tabel 4. Perlu diketahui sebagai desain awal bahwa margin padam minimum atau reaktivitas padam harus dipenuhi yang merupakan persyaratan mutlak untuk desain teras setimbang. 
Konfigurasi teras $5 \times 5$, Gambar 1 dan

Tabel 1, terdiri dari 16 elemen bakar standar (FE) dan 4 elemen bakar kendali (CE) serta 5 posisi iradiasi dalam teras (IP0, IP1, IP2, IP3 dan IP4). Tabel 4 menunjukkan konstanta makroskopik bahan bakar fungsi frasi bakar teras TRIGA dengan muatan 250 gram atau densitas 2,95 gU/cc. Konstanta makroskopik ini sangat penting dilakukan secara akurat karena menentukan dalam perhitungan teras. Nilai K-inf turun dengan bertambahnya nilai fraksi pembakaran demikian juga dengan masa uranium U-235 berkurang. Hal ini sudah sesuai dengan harapan.

Tabel 4. Konstanta makroskopik bahan bakar hasil perhitungan WIMSD-5B

\begin{tabular}{|c|c|c|c|c|c|c|}
\hline $\begin{array}{l}\text { Fraksi } \\
\text { bakar }\end{array}$ & K-inf & Buckling & Masa ${ }^{235} \mathrm{U}$ & \multicolumn{3}{|c|}{ Buckling } \\
\hline & & IFS 4 & & IFS1 & IFS2 & IFS4 \\
\hline 0 & $1,56 \mathrm{E}+00$ & $8,04 \mathrm{E}-03$ & $1,50 \mathrm{E}-03$ & $8,87 \mathrm{E}-03$ & $8,87 \mathrm{E}-03$ & $8,66 \mathrm{E}-03$ \\
\hline 0.1 & $1,56 \mathrm{E}+00$ & $8,03 \mathrm{E}-03$ & $1,50 \mathrm{E}-03$ & $8,90 \mathrm{E}-03$ & $8,85 \mathrm{E}-03$ & $8,64 \mathrm{E}-03$ \\
\hline 0.6 & $1,55 \mathrm{E}+00$ & $8,04 \mathrm{E}-03$ & 1,49E-03 & $8,80 \mathrm{E}-03$ & $8,74 \mathrm{E}-03$ & $8.54 \mathrm{E}-03$ \\
\hline 5 & $1,53 \mathrm{E}+00$ & $8,04 \mathrm{E}-03$ & $1,43 \mathrm{E}-03$ & $8.50 \mathrm{E}-03$ & $8,34 \mathrm{E}-03$ & $8,14 \mathrm{E}-03$ \\
\hline 11 & $1,50 \mathrm{E}+00$ & 8.03E-03 & $1,35 \mathrm{E}-03$ & $8,10 \mathrm{E}-03$ & $7,93 \mathrm{E}-03$ & $7,73 \mathrm{E}-03$ \\
\hline 17 & $1,48 \mathrm{E}+00$ & 7,92E-03 & $1,28 \mathrm{E}-03$ & $7,67 \mathrm{E}-03$ & $7,49 \mathrm{E}-03$ & $7,29 \mathrm{E}-03$ \\
\hline 23 & $1,45 \mathrm{E}+00$ & 7,53E-03 & $1,22 \mathrm{E}-03$ & $7,20 \mathrm{E}-03$ & $7,01 \mathrm{E}-03$ & $6,82 \mathrm{E}-03$ \\
\hline 29 & $1,42 \mathrm{E}+00$ & $7,12 \mathrm{E}-03$ & $1,16 \mathrm{E}-03$ & $6,70 \mathrm{E}-03$ & $6,49 \mathrm{E}-03$ & $6,30 \mathrm{E}-03$ \\
\hline 35 & $1,39 \mathrm{E}+00$ & $6,68 \mathrm{E}-03$ & $1,11 \mathrm{E}-03$ & $6,10 \mathrm{E}-03$ & $5,90 \mathrm{E}-03$ & $5,72 \mathrm{E}-03$ \\
\hline 41 & $1,35 \mathrm{E}+00$ & $6,21 \mathrm{E}-03$ & $1,07 \mathrm{E}-03$ & $5,40 \mathrm{E}-03$ & $5,25 \mathrm{E}-03$ & $5,09 \mathrm{E}-03$ \\
\hline 47 & $1,31 \mathrm{E}+00$ & $5,70 \mathrm{E}-03$ & $102 \mathrm{E}-03$ & $4,70 \mathrm{E}-03$ & $4,52 \mathrm{E}-03$ & $4,36 \mathrm{E}-03$ \\
\hline 53 & $1,26 \mathrm{E}+00$ & $5,12 \mathrm{E}-03$ & $9,80 \mathrm{E}-04$ & $3,85 \mathrm{E}-03$ & $3,68 \mathrm{E}-03$ & $3,55 \mathrm{E}-03$ \\
\hline 60 & $1,20 \mathrm{E}+00$ & 4,49E-03 & $9,37 \mathrm{E}-04$ & 2,70E-03 & $2,56 \mathrm{E}-03$ & $2,44 \mathrm{E}-03$ \\
\hline 68 & $1,12 \mathrm{E}+00$ & $3,77 \mathrm{E}-03$ & $8,88 \mathrm{E}-04$ & $1,13 \mathrm{E}-03$ & $9,83 \mathrm{E}-04$ & $8,99 \mathrm{E}-04$ \\
\hline 75 & $1,02 \mathrm{E}+00$ & 2,97E-03 & $8,58 \mathrm{E}-04$ & $-7,10 \mathrm{E}-04$ & $-8,45 \mathrm{E}-04$ & $-8,89 \mathrm{E}-04$ \\
\hline 82 & $9,05 \mathrm{E}-01$ & $1,88 \mathrm{E}-03$ & $8,24 \mathrm{E}-04$ & $-3,10 \mathrm{E}-03$ & $-3,21 \mathrm{E}-03$ & $-3,20 \mathrm{E}-03$ \\
\hline 90 & $7,18 \mathrm{E}-01$ & $3,76 \mathrm{E}-04$ & $7,90 \mathrm{E}-04$ & $-7,20 \mathrm{E}-03$ & $-7,27 \mathrm{E}-03$ & $-7,14 \mathrm{E}-03$ \\
\hline
\end{tabular}

Tabel 5 menunjukkan tampang lintang makroskopik material penyerap AgInCd. Material ini merupakan batang kendali penyerap neutron dan pengendali reaktivitas teras yang sudah teruji di teras RSG-GAS selama lebih 30 tahun beroperasi.

Reflektor grafit digunakan pada teras TRIGA tipe pelat dan material berilium. Material ini mengandung impurities dari beberapa elemen seperti besi, silikon dan aluminium. Impurities besi mempunyai tampang lintang absorbsi yang sangat tinggi terhadap neutron termal. Oleh karena itu konsentrasi grafit dan berilium mempengaruhi efisiensi reflektor dan konsentrasi grafit serta berilium dijaga serendah mungkin. Keefektifan reflektor sangat mempengaruhi nilai k-eff teras pada perhitungan teras. Pada Tabel 6 dan Tabel 7 merupakan nilai tampang lintang 
makroskopik reflektor grafit, dan material berilium sebagai pembentuk teras TRIGA berbahan bakar pelat. Konstanta makroskopik tersebut dihitung dengan 4 energi grup yang digunakan sebagai input pada perhitungan teras BATAN-2DIFF. Konstanta makroskopik tersebut adalah konstanta difusi (D), tampang lintang serapan $\left(\Sigma_{\mathrm{a}}\right)$, tampang lintang fisi dikali jumlah neutron per fisi $\left(\mathrm{nu} \Sigma_{\mathrm{f}}\right)$. Konstanta difusi untuk reflektor grafit lebih besar dibandingkan dengan berilium dan konstanta serapannya juga lebih besar grafit. Dari kedua nilai konstanta makroskopik ini dapat dinyatakan bahwa yang paling banyak menyerap neutron adalah grafit. Fungsi dari reflektor bukan menyerap neutron melainkan memantulkan neutron kembali ke teras sehingga bisa berfisi dengan bahan bakar uranium. Tapi jika dibandingkan dengan konstanta serapan $\left(\Sigma_{\mathrm{a}}\right)$, paling besar yaitu pada energy group pertama adalah $3,9273 \mathrm{E}$ 03 sedangkan grafit 1,18827E-04 serta berilium 1,02907E-04. Jelas bahwa fungsi dari batang kendali AgInCd adalah menyerap neutron sehingga teras reaktor bisa dikendalikan. Setelah selesai perhitungan tampang lintang makroskopik maka akan dibuat library untuk perhitungan teras yang digunakan dalam perhitungan teras.
Tabel 5. Konstanta makroskopik AgInCd

\begin{tabular}{llll} 
Material & $\begin{array}{l}\text { Grup } \\
\text { neutron }\end{array}$ & $\begin{array}{l}\text { Kostanta makroskopik } \\
\text { (konstanta difusi, sigma } \\
\text { serapan) }\end{array}$ \\
\hline \multirow{3}{*}{ AgInCd } & 1 & $1,93136 \mathrm{E}+00$ & $3,92735 \mathrm{E}-03$ \\
& & $0,00000 \mathrm{E}+00$ & $0,00000 \mathrm{E}+00$ \\
& $0,00000 \mathrm{E}+00$ & $1,23280 \mathrm{E}-01$ \\
& $4,52550 \mathrm{E}-02$ & $1,32170 \mathrm{E}-04$ \\
& $3,53250 \mathrm{E}-11$ \\
& $1,04904 \mathrm{E}+00$ & $2,48314 \mathrm{E}-02$ \\
& $0,00000 \mathrm{E}+00$ & $0,00000 \mathrm{E}+00$ \\
& $0,00000 \mathrm{E}+00$ & $0,00000 \mathrm{E}+00$ \\
& $2,91940 \mathrm{E}-01$ & $9,78800 \mathrm{E}-04$ \\
& $0,00000 \mathrm{E}+00$ & \\
& $2,10663 \mathrm{E}-01$ & $1,15470 \mathrm{E}+00$ \\
& $0,00000 \mathrm{E}+00$ & $0,00000 \mathrm{E}+00$ \\
& $0,00000 \mathrm{E}+00$ & $0,00000 \mathrm{E}+00$ \\
& $0,00000 \mathrm{E}+00$ & $4,27470 \mathrm{E}-01$ \\
& $1,99680 \mathrm{E}-04$ \\
& $4,78622 \mathrm{E}-02$ & $6,7146 \mathrm{E}+00$ \\
& $0,00000 \mathrm{E}+00$ & $0,00000 \mathrm{E}+00$ \\
& $0,00000 \mathrm{E}+00$ & $0,00000 \mathrm{E}+00$ \\
& $0,00000 \mathrm{E}+00$ & $1,28280 \mathrm{E}-03$ \\
& $2,485200 \mathrm{E}-01$ &
\end{tabular}

Library bahan bakar uranium silisida yang digenerasi dengan massa yang berbeda dijadikan satu library sehingga penggunaannya dapat untuk perhitungan lainnya pada program BATAN-FUEL.

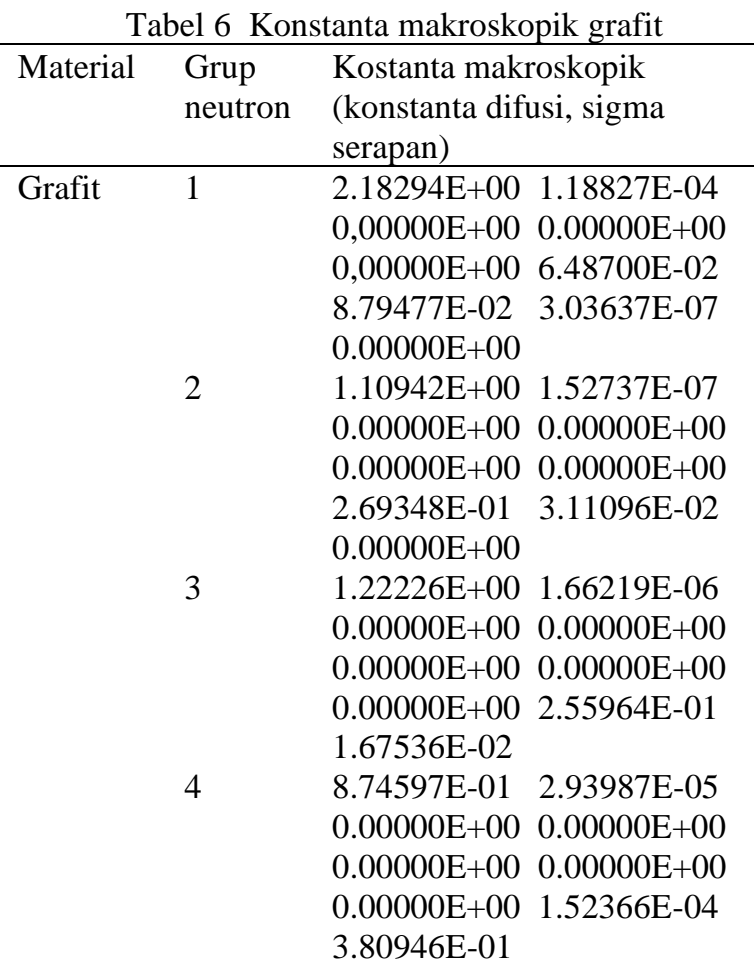


Tabel 7. Konstanta makroskopik Berilium

\begin{tabular}{|c|c|c|}
\hline Material & $\begin{array}{l}\text { Grup } \\
\text { neutron }\end{array}$ & $\begin{array}{l}\text { Kostanta makroskopik } \\
\text { (konstanta difusi, sigma } \\
\text { serapan) }\end{array}$ \\
\hline & 1 & 1,64844E+00 1,02907E-04 \\
\hline \multirow[t]{19}{*}{$\mathrm{Be}$} & & $0,00000 \mathrm{E}+00 \quad 0,00000 \mathrm{E}+00$ \\
\hline & & 0,00000E+00 1,75090E-01 \\
\hline & & 2,70195E-02 7,61086E-08 \\
\hline & & $0,00000 \mathrm{E}+00$ \\
\hline & 2 & $7,70357 \mathrm{E}-01 \quad 1,51449 \mathrm{E}-07$ \\
\hline & & $0,00000 \mathrm{E}+00 \quad 0,00000 \mathrm{E}+00$ \\
\hline & & $0,00000 \mathrm{E}+00 \quad 0,00000 \mathrm{E}+00$ \\
\hline & & $4,21076 \mathrm{E}-01 \quad 1,16238 \mathrm{E}-02$ \\
\hline & & $0,00000 \mathrm{E}+00$ \\
\hline & 3 & $6,58823 \mathrm{E}-01 \quad 1,58783 \mathrm{E}-05$ \\
\hline & & $0,00000 \mathrm{E}+00 \quad 0,00000 \mathrm{E}+00$ \\
\hline & & $0,00000 \mathrm{E}+00 \quad 0,00000 \mathrm{E}+00$ \\
\hline & & $0,00000 \mathrm{E}+00 \quad 4,98050 \mathrm{E}-01$ \\
\hline & & $7,88676 \mathrm{E}-03$ \\
\hline & 4 & $6,24776 \mathrm{E}-01 \quad 2,58370 \mathrm{E}-04$ \\
\hline & & $0,00000 \mathrm{E}+00 \quad 0,00000 \mathrm{E}+00$ \\
\hline & & $0,00000 \mathrm{E}+00 \quad 0,00000 \mathrm{E}+00$ \\
\hline & & $0,00000 \mathrm{E}+00 \quad 3,26441 \mathrm{E}-04$ \\
\hline & & $5,29400 \mathrm{E}-01$ \\
\hline
\end{tabular}

\section{Perhitungan Teras}

Perhitungan parameter neutronik teras TRIGA tipe pelat dilakukan dengan menggunakan program BATAN-FUEL yang dilengkapi dengan fitur mencari teras setimbang. Tabel 8 merupakan hasil peritungan parameter neutronik teras TRIGA2000 konversi.

Tabel 8. Parameter neutronik hasil perhitungan

\begin{tabular}{|c|c|}
\hline Parameter teras & Nilai \\
\hline Kerapatan uranium $(\mathrm{g} / \mathrm{cc})$ & 2,96 \\
\hline Daya & $2 / 240$ \\
\hline Reaktivitas satu siklus, $\% \Delta \mathrm{k} / \mathrm{k}$ & 4,542 \\
\hline Reakt & 6,827 \\
\hline Cold $\mathrm{t}$ & 0,501 \\
\hline $\begin{array}{l}\text { Eksperimen dan Xe Override, } \\
\% \Delta \mathrm{k} / \mathrm{k}\end{array}$ & 1,0759 \\
\hline Reaktivitas lebih, $\% \Delta \mathrm{k} / \mathrm{k}$ & 8,404 \\
\hline Nilai & $-19,573$ \\
\hline $\begin{array}{l}\text { Reaktivitas padam (stuck rod), } \\
\% \Delta \mathrm{k} / \mathrm{k}\end{array}$ & $-4,171$ \\
\hline Rapat daya (W/cc) & 28,305 \\
\hline PD radial rata- & 1,2971 \\
\hline Fraksi bakar maksimum, $\%$ & 16,401 \\
\hline
\end{tabular}

Dari aspek pengendalian reaktivitas, teras TRIGA dengan reflektor grafit memiliki nilai margin padam minimum (kondisi stuck rod) memenuhi kriteria keselamatan yaitu minimum $-0,5 \% \Delta \mathrm{k} / \mathrm{k}$. Nilai reaktivitas batang kendali lebih besar dari nilai rektivitas lebih teras yang artinya batang kendali dapat mengendalikan reaktor dan beroperasi baik pada daya rendah maupun daya tinggi. Kondisi stuck rod artinya pada saat $1 \mathrm{CE}$ yang mempunyai nilai reaktivitas terbesar mengalami gagal masuk ke teras memberikan nilai perlipatan efektif (untuk kondisi subkritis), $\mathrm{k}_{\mathrm{eff}}<1$. Hal ini terjadi untuk seluruh konfigurasi yang dibentuk dan tingkat muat ${ }^{235} \mathrm{U} 250$ gram. Hasil perhitungan menunjukkan bahwa kriteria keselamatan untuk margin padam minimum sebesar $-0,5 \quad \% \Delta \mathrm{k} / \mathrm{k}$ dapat dipenuhi untuk teras dengan reflektor grafit, tingkat muat ${ }^{235} \mathrm{U}$ sebesar 250 gram.

Dari aspek kerataan pembangkitan panas yang ditunjukkan dengan nilai FPD radial maksimum masih memenuhi syarat, terlihat jelas bahwa nilai FPD maksimum sangat dipengaruhi oleh jenis reflektor dan tingkat muat ${ }^{235} \mathrm{U}$. Oleh karena itu faktor utama dalam penentuan nilai PD (power density) maksimum adalah distribusi fraksi bakar FE dan CE disekitar posisi iradiasi (IP). Nilai PD radial maksimum untuk reflektor grafit lebih kecil dari pada nilai kriteria keselamatan 1,4. 
Susunan bahan bakar teras awal TRIGA2000 dinyatakan pada Gambar 6 yang terdiri dari 16 bahan bakar dan 4 batang kendali. Teras-1 susunan bahan bakar seperti Gambar 7, Susunan bahan bakar pada teras-2 seperti pada Gambar 8 dan susunan bahan bakar pada teras-3 seperti yang ditunjukkan pada Gambar 9. Penempatan bahan bakar tiap teras diatur mengikuti kaidah teras setimbang. Penempatan bahan bakar pada teras setimbang ini sangat bervariasi kemungkinannya namun dalam perhitungan ini dipilih yang seperti Gambar di atas. Dari hasil perhitungan diperoleh nilai fraksi bakar setiap bahan bakar pada panjang siklus 3 x 100 hari reaktor beroperasi denagan daya $2 \mathrm{MW}$ dan terakhir 50 hari operasi, sehingga total 350 hari.

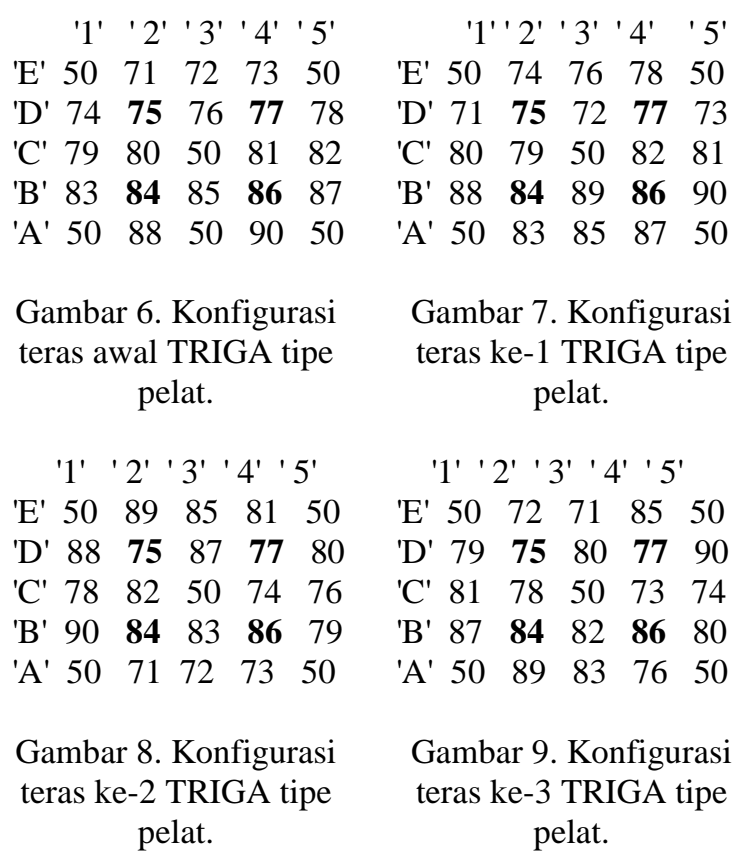

Jumlah uranium di dalam teras TRIGA2000 awal adalah 4714,29 gram. Reaktor dioperasikan dengan daya $2 \mathrm{MW}$ selama seratus hari maka uranium yang ada di dalam teras berkurang seperti pada Tabel 8 teras-1 (lajur 4). Dioperasikan lagi 100 hari dengan daya $2 \mathrm{MW}$ diperoleh sisa hasil uranium di dalam pada lajur 5 atau teras- 2 dan demikian seterusnya. Pada akhir teras dihitung fraksi bakar semua bakan bakar diperoleh nilai fraksi bakar tertinggi adalah $23,85 \%$ yaitu pada nomor material bahan bakar 81. Setelah itu dilakukan pergantian bahan bakar baru. Salah satu pola manajemen bahan bakar teras TRIGA2000 tipe pelat yang diusulkan adalah seperti pada Tabel 9. 
Tabel 9. Fraksi bakar teras TRIGA hasil perhitungan.

\begin{tabular}{|c|c|c|c|c|c|c|c|}
\hline No & $\mathrm{BB}$ & $\begin{array}{l}\text { Teras-0 } \\
\text { (gram) }\end{array}$ & $\begin{array}{l}\text { Teras-1 } \\
\text { (gram) }\end{array}$ & $\begin{array}{l}\text { Teras-2 } \\
\text { (gram) }\end{array}$ & $\begin{array}{l}\text { Teras-3 } \\
\text { (gram) }\end{array}$ & $\begin{array}{l}\text { Teras-4 } \\
\text { (gram) }\end{array}$ & $\begin{array}{l}\text { Deflesi } \\
(\%)\end{array}$ \\
\hline 1 & 71 & 250,0000 & 238,1045 & 226,3757 & 214,4151 & 208,7893 & 16,45 \\
\hline 2 & 72 & 250,0000 & 238,9024 & 222,8288 & 211,7195 & 205,7856 & 17,69 \\
\hline 3 & 73 & 250,0000 & 238,0994 & 226,3763 & 214,4571 & 205,9214 & 17,63 \\
\hline 4 & 74 & 250,0000 & 238,2926 & 226,3816 & 209,4757 & 203,7924 & 18,48 \\
\hline 5 & 75 & 178,5725 & 168,3047 & 158,0601 & 147,8530 & 142,7459 & 20,06 \\
\hline 6 & 76 & 250,0000 & 233,9876 & 222,9503 & 211,6860 & 205,7344 & 17,71 \\
\hline 7 & 77 & 178,5725 & 168,2992 & 158,0523 & 147,8686 & 142,7440 & 20,06 \\
\hline 8 & 78 & 250,0000 & 238,2825 & 226,3753 & 214,9748 & 206,4491 & 17,42 \\
\hline 9 & 79 & 250,0000 & 238,6843 & 221,7410 & 210,9032 & 205,0602 & 17,98 \\
\hline 10 & 80 & 250,0000 & 233,1021 & 221,8622 & 210,3170 & 204,4596 & 18,22 \\
\hline 11 & 81 & 250,0000 & 233,0934 & 207,1976 & 195,8468 & 190,3742 & 23,85 \\
\hline 12 & 82 & 250,0000 & 2386739 & 236,6503 & 219,3462 & 211,1623 & 15,54 \\
\hline 13 & 83 & 250,0000 & 238.2881 & 226,3688 & 210,2481 & 204,6796 & 18,13 \\
\hline 14 & 84 & 178,5725 & 168,2999 & 158,1195 & 147,8724 & 142,7699 & 20,05 \\
\hline 15 & 85 & 250,0000 & 233,9805 & 222,9351 & 211,8727 & 205,9171 & 17,63 \\
\hline 16 & 86 & 178,5725 & 168,2948 & 158,0437 & 147,8232 & 142,7030 & 20,09 \\
\hline 17 & 87 & 250,0000 & 238,2786 & 226,3636 & 210,3139 & 204,4796 & 18,21 \\
\hline 18 & 88 & 250,0000 & 238,0959 & 226,3630 & 214,6132 & 206,5097 & 17,39 \\
\hline 19 & 89 & 250,0000 & 238,8939 & 222,8138 & 210,2540 & 204,3381 & 18,26 \\
\hline 20 & 90 & 250,0000 & 238,0913 & 226,3647 & 214,5787 & 208,6642 & 16,53 \\
\hline
\end{tabular}

Perhitungan pola manajemen bahan bakar teras TRIGA2000 equilibrium yang lain adalah seperti berikut: dimulai dengan konfigurasi teras awal seperti Gambar 8, kemudian untuk teras equilibrium ini disebut teras awal. Kemudian reaktor dioperasikan dengan daya 2 MW selama 50 hari. Kemudian bahan bakar direshufle seperti Gambar 10 disebut teras-1. Kemudian bahan bakar direshufle seperti gambar 11 disebut teras-2 dan reaktor diperasikan lagi 50 hari dengan daya 2 MW. Demikian seterusnya teras-3, teras- 4 , teras-5, teras-6 dan teras- 7 ,

masing masing pada gambar $12,13,14,15$ dan 16.

$\begin{array}{lllllll}\text { '1' } & \text { 2' } & \text { ' 3' ' ' 4' ' 5' } \\ \text { 'E' } & 50 & 71 & 72 & 73 & 50 \\ \text { 'D' } & 74 & \mathbf{7 5} & 76 & \mathbf{7 7} & 78 \\ \text { 'C' } & 79 & 80 & 50 & 81 & 82 \\ \text { 'B' } & 83 & \mathbf{8 4} & 85 & \mathbf{8 6} & 87 \\ \text { 'A' } & 50 & 88 & 89 & 90 & 50 \\ \text { Gambar } & 10 . \\ \text { teras awnal }\end{array}$ '1' ' 2' '3' '4' ' 5' 'E' $\begin{array}{lllll}50 & 89 & 85 & 90 & 50\end{array}$ 'D' $87 \begin{array}{lllll}75 & 88 & \mathbf{7 7} & 80\end{array}$ 'C' $\begin{array}{lllll}78 & 82 & 50 & 71 & 76\end{array}$ 'B' $81 \quad 84 \quad 73 \quad 86 \quad 79$ 'A' $\begin{array}{lllll}50 & 74 & 72 & 83 & 50\end{array}$

Gambar 12. Konfigurasi teras ke-2 TRIGA2000
'1' ' 2' ' 3' ' 4' ' 5'

'E' $50 \quad 74 \quad 76 \quad 78 \quad 50$

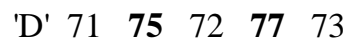

'C' $80 \begin{array}{llll}79 & 50 & 82 & 81\end{array}$

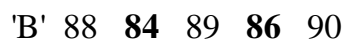
'A' $\begin{array}{lllll}50 & 83 & 85 & 87 & 50\end{array}$ Gambar 11. Konfigurasi teras ke-1 TRIGA2000

'1' ' 2' ' 3' ' 4' ' 5'

$\begin{array}{llllll}\text { 'E' } & 50 & 72 & 71 & 85 & 50\end{array}$

$\begin{array}{llllll}\text { 'D' } & 79 & \mathbf{7 5} & 87 & \mathbf{7 7} & 90\end{array}$

$\begin{array}{llllll}\text { 'C' } & 81 & 78 & 50 & 82 & 73\end{array}$

$\begin{array}{llllll}\text { 'B' } & 88 & \mathbf{8 4} & 74 & \mathbf{8 6} & 80\end{array}$

'A' $\begin{array}{lllll}50 & 89 & 83 & 76 & 50\end{array}$

Gambar 13. Konfigurasi teras ke-3 TRIGA2000 
'1' '2' '3' ' 4' ' 5'

'1' ' 2' ' 3' ' 4' ' 5'

'E' $\begin{array}{lllll}50 & 74 & 76 & 78 & 50\end{array}$

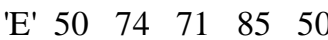

'D' $87 \quad 75 \quad 79 \quad 77 \quad 90$

'C' $81 \quad 76 \quad 50 \quad 89 \quad 73$

'B' $88 \quad 84 \quad 72 \quad 86 \quad 80$

'A' $\begin{array}{llllll}50 & 82 & 83 & 78 & 50\end{array}$

Gambar 15. Konfigurasi teras ke-5 TRIGA2000 teras ke-4 TRIGA2000

$$
\text { '1' ' 2' '3' ' 4' ' 5' }
$$

'E' $\begin{array}{lllll}50 & 74 & 83 & 78 & 50\end{array}$

'D' $71 \quad \mathbf{7 5} \quad 72 \quad \mathbf{7 6} \quad 85$

'C' $80 \begin{array}{lllll}76 & 50 & 73 & 81\end{array}$

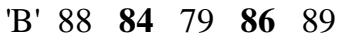

'A' $\begin{array}{lllll}50 & 82 & 90 & 87 & 50\end{array}$

Gambar 16. Konfigurasi

teras ke-6 TRIGA2000
2 dapat dilihat pada Tabel 10. Hasil perhitungan BATAN-FUEL menunjukkan bahwa pola operasi ini diperoleh fraksi bakar maksimum sekitar 20,14 \%. Hal ini tidak signifikan perbedaannya dengan pola operasi yang pertama dan menunjukkan bahwa pola operasi atau konfigurasi teras tidak dapat meningkatkan fraksi bakar yang dapat meningkatkan fraksi bakar hanya dengan memperlebar teras atau menambah jumlah bahan bakar.

Hasil perhitungan nilai fraksi bakar teras

TRIGA2000 dengan pola operasi model ke-

Tabel 10. Hasil perhitungan fraksi bakar teras TRIGA2000

\begin{tabular}{|c|c|c|c|c|c|c|c|c|c|c|}
\hline No & BB & $\begin{array}{l}\text { Teras-0 } \\
\text { (gram) }\end{array}$ & $\begin{array}{l}\text { Teras-1 } \\
\text { (gram) }\end{array}$ & $\begin{array}{l}\text { Teras-2 } \\
\text { (gram) }\end{array}$ & $\begin{array}{l}\text { Teras-3 } \\
\text { (gram) }\end{array}$ & $\begin{array}{l}\text { Teras-4 } \\
\text { (gram) }\end{array}$ & $\begin{array}{l}\text { Teras-5 } \\
\text { (gram) }\end{array}$ & $\begin{array}{l}\text { Teras-6 } \\
\text { (gram) }\end{array}$ & $\begin{array}{l}\text { Teras-7 } \\
\text { (gram) }\end{array}$ & $\begin{array}{l}\text { Deflesi } \\
(\%)\end{array}$ \\
\hline 1 & 71 & 250,0000 & 244,0324 & 238,1531 & 229,6542 & 224,0905 & 218,2280 & 212,6378 & 206,7584 & 17,29 \\
\hline 2 & 72 & 250,0000 & 244,4337 & 236,3789 & 230,8154 & 224,8657 & 218,9022 & 212,9467 & 204,8708 & 18,51 \\
\hline 3 & 73 & 250,0000 & 244,0298 & 238,1492 & 230,0906 & 224,4031 & 218,5341 & 212,8225 & 204,3275 & 18,27 \\
\hline 4 & 74 & 250,0000 & 244,1270 & 238,1545 & 232,1857 & 224,1169 & 218,1680 & 210,1094 & 204,1825 & 18,33 \\
\hline 5 & 75 & $\mathbf{1 7 8 , 5 7 2 5}$ & 173,4190 & 168,2701 & 163,1283 & 157,9975 & 152,8649 & 147,7428 & 142,6216 & 20,13 \\
\hline 6 & 76 & 250,0000 & 241,9612 & 236,4080 & 230,7291 & 224,7653 & 219,1794 & 213,2051 & 204,6999 & 18,12 \\
\hline 7 & 77 & $\mathbf{1 7 8 , 5 7 2 5}$ & 173,4163 & 168,2726 & 163,1265 & 157,9857 & 152,6561 & 147,7257 & 142,6111 & 20,14 \\
\hline 8 & 78 & 250,0000 & 244,1219 & 238,1490 & 232,4560 & 223,9546 & 218,0090 & 209,5353 & 203,6228 & 18,55 \\
\hline 9 & 79 & 250,0000 & 244,3240 & 235,8275 & 229,9700 & 224,1187 & 218,5360 & 212,6674 & 204,5917 & 18,16 \\
\hline 10 & 80 & 250,0000 & 241,5155 & 235,8563 & 229,9990 & 224,1279 & 218,4370 & 212,5572 & 206,8399 & 17,26 \\
\hline 11 & 81 & 250,0000 & 241,5111 & 228,4397 & 222,6714 & 217,0875 & 211,4845 & 205,8737 & 200,2499 & 19,90 \\
\hline 12 & 82 & 250,0000 & 244,3188 & 243,3073 & 234,7365 & 226,1858 & 218,1103 & 209,6284 & 2037034 & 18,52 \\
\hline 13 & 83 & 250,0000 & 244,1248 & 238,1481 & 232,1748 & 226,5780 & 218,0615 & 212,4672 & 206,8631 & 17,25 \\
\hline 14 & 84 & 178,5725 & 173,4166 & 168,2654 & 163,1196 & 157,9856 & 152,8508 & 147,7249 & 142,6012 & 20,14 \\
\hline 15 & 85 & 250,0000 & 241,9576 & 236,4003 & 230,8336 & 224,8707 & 216,3851 & 210,4544 & 204,6092 & 18,17 \\
\hline 16 & 86 & 178,5725 & 173,4140 & 168,2609 & 163,1145 & 157,9698 & 152,8381 & 147,7044 & 142,6074 & 20,14 \\
\hline 17 & 87 & 250,0000 & 244,1200 & 238,1432 & 232,2641 & 224,1964 & 218,2429 & 212,4946 & 204,2623 & 18,29 \\
\hline 18 & 88 & 250,0000 & 244,0281 & 238,1467 & 230,0868 & 224,2311 & 218,3641 & 212,4946 & 206,6154 & 17,53 \\
\hline 19 & 89 & 250,0000 & 244,4294 & 236,3712 & 230,4246 & 224,4755 & 218,6035 & 212,6444 & 206,7675 & 17,29 \\
\hline 20 & 90 & 250,0000 & 244,0258 & 238,1434 & 232,1706 & 226,2766 & 218,1950 & 212,2399 & 206,6332 & 17,35 \\
\hline
\end{tabular}


Hasil perhitungan fluks neutron termal pada fasilitas iradiasi dapat dilihat pada gambar 17. Fluks termal yang paling tinggi diperoleh di fasilitas iradiasi tengah yaitu sekitar $5,5 \times 10^{13} \mathrm{n} / \mathrm{cm}^{2} \mathrm{~s}$, sedangkan pada fasilitas dipinggir teras sekitar 2,5 $\times 10^{13}$ $\mathrm{n} / \mathrm{cm}^{2} \mathrm{~s}$. Hal ini sudah sesuai dengan yang diharapkan untuk dapat mengiradiasi sampel atau memproduksi radioisotop yang sesuai dengan peruntukannya.

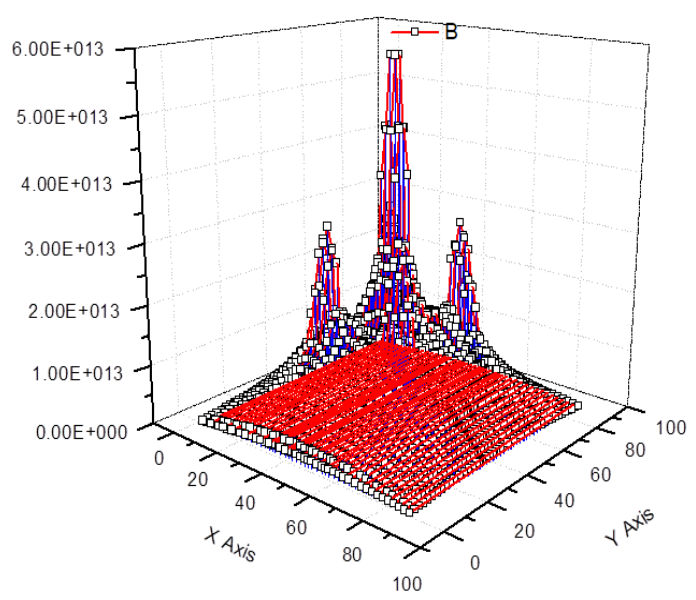

Gambar 17. Fluks neutron termal pada teras TRIGA2000

\section{KESIMPULAN}

Dari hasil analisis menunjukkan bahwa pola manajemen bahan bakar teras pada konfigurasi teras $5 \times$ x 5 tidak dapat menaikkan fraksi bakar yang diharapkan. Pola manajemen bahan bakar di dalam teras hanya dapat memperpanjang siklus operasi. Jika dibandingkan kedua pola manajemen bahan bakar tersebut maka pola manajemen bahan bakar yang pertama lebih baik karena pola yang ke dua dibutuhkan waktu untuk pembongkaran dan penyusunan bahan bakar yang lebih lama.

\section{UCAPAN TERIMAKASIH}

Penulis mengucapkan terimakasih kepada Ka. PTKRN yang telah memberikan kesempatan untuk melakukan penelitian di PTKRN.

\section{DAFTAR PUSTAKA}

[1]. KHOT P.M., SINGH G., SHELKE B.K., SURENDRA B., YADAV M.K., MISHRA A.K., AFZAL M., PANAKKAL J.P. Development of recycling processes for clean rejected MOX fuel pellets. Nuclear Engineering and Design. 2014. 270: 227-237

[2]. PINEM S., SEMBIRING T.M., SURBAKTI T. Core Conversion Design Study of TRIGA Mark 2000 Bandung using MTR Pelate Type Fuel Element. Int. J. Nucl. Energy Sci. Technol. 2018. 12(3):222-238.

[3]. SURBAKTI T., PINEM S., SEMBIRING T. M. Analisis Pengaruh Densitas Bahan Bakar Silisida Terhadap Parameter Kinetik Teras Reaktor RSG-GAS. Jurnal Penelitian Fisika dan Aplikasinya. 2013; 3(1): 19-30.

[4]. SURBAKTI T., PINEM S, SEMBIRING T. M., SUPARLINA L., SUSILO J. Desain Konseptual 
Teras Reaktor Riset Inovatif Berbahan Bakar Uraniummolibdenum dari Aspek Neutronik. Tri Dasa Mega. 2012; 3(14): 178191.

[5]. LIEM P. H., SURBAKTI T., HARTANTO D. Kinetics parameters evaluation on the first core of the RSG GAS (MPR-30) using continuous energy Monte Carlo method. Progress in Nuclear Energy. 2018; 109: 196-203

[6]. SURBAKTI T., PINEM S, SEMBIRING T. M., HAMZAH A., NABESHIMA K. Calculation of Control Rods Reactivity Worth of RSG-GAS First Core Using Deterministic and Monte Carlo Methods. Atom Indonesia. 2019; 45 (2), 69-79.

[7]. SURBAKTI T., PURWADI P. Analysis of Neutronic Safety Parameters of the Multi-Purpose Reactor-Gerrit Augustinus Siwabessy (RSG-GAS) Research Reactor at Serpong. J. Penelit. Fis. dan Apl. 2019. 9(1):78-91.

[8]. DAWAHRA S., KHATTAB K., SABA G. Extending the Maximum Operation Time of the MNSR Reactor. Appl. Radiat. Isot. 2016. 115:256-261.

[9]. DAWAHRA S., KHATTAB K., SABA G. Calculation and
Comparison of Xenon and Samarium Reactivities of the HEU, LEU Core in the Low Power Research Reactor. Appl. Radiat. Isot. 2015. 101:27-32.

[10]. SURBAKTI T., PINEM S., SUPARLINA L. Dynamic Analysis on the Safety Criteria of the Conceptual Core Design in MTRtype Research Reactor. Atom Indones. 2018. 44(2):89-97.

[11]. SURBAKTI T., PINEM S., SEMBIRING T.M., Subekti M., Sunaryo G.R. Preliminary Study for Alternative Conceptual Core Design of the MTR Research Reactor. J. Phys. Conf. Ser. 2018. 962(1)

[12]. HEDAYAT A. Benchmarking Verification of the Control Rod Effects on the MTR Core Parameters using the MTR-PC and MCNP Codes throughout 3D Core Modeling and Rod-drop Experiment. Prog. Nucl. Energy. 2016. 88:183-190.

[13]. LIU Z., SMITH K., FORGET B. Calculation of Multi-group Migration Areas in Deterministic Transport Simulations. Ann. Nucl. Energy. 2020. 140:107-110.

[14]. PINEM S., LIEM P.H., SEMBIRING T.M., SURBAKTI T. Fuel Element Burnup Measurements for the Equilibrium LEU Silicide RSG GAS (MPR-30) Core under a 
New Fuel Management Strategy.

Ann. Nucl. Energy. 2016. 98

[15]. VILLARINO E.A., MOCHI I.

Thermal-hydraulic Models for

Neutronic and thermaly- hydraulic

Feedback in Citvap Code. 2014.

23:23-36.

[16]. SURBAKTI T., IMRON M. Fuel Burn-up Calculation for Working

Core of the RSG-GAS Research

Reactor at Batan Serpong. J. Penelit.

Fis. dan Apl. 2017. 7(2):89-101.

[17]. PINEM S., SURBAKTI T.,

SEMBIRING T., ET AL.

Optimization of Radioisotope

Production at RSG-GAS Reactor

using Deterministic Method. Journal

Teknologi Indonesia 2016. 1

(2):12-18. 